\title{
Interfaith Dialogue versus Recent Hatred: Serbian Orthodoxy and Croatian Catholicism from the Second Vatican Council to the Yugoslav War, 1965-1992
}

\author{
VJEKOSLAV PERICA
}

Relations between the two largest denominations, the Serbian Orthodox Church and the Croatian branch of the Roman Catholic Church, were critically important for Yugoslavia as a country in which ethnic and religious identities coincided and relations between the churches affected relations between two major nationalities, Orthodox Serbs and Catholic Croats. Premodern controversies, such as the Church Schism of 1054, the Counter-Reformation, 'Uniatism' which originated in the sixteenth century and church quarrels associated with the establishment of Serbian Orthodox dioceses in Habsburg lands after 1690, are still alive in people's memories. In the second half of the twentieth century, however, the two major Yugoslav religious institutions came into conflict primarily as a result of 'recent hatreds' generated by the Second World War.

\section{The Impulse for Dialogue ${ }^{1}$}

Returning from Rome after the adjournment of the Second Vatican Council to his diocese, Split-Makarska in southern Croatia, Bishop Dr Frane Franic harked back to the historic hug between Pope Paul VI and the Orthodox Ecumenical Patriarch Athenagoras. The idea of reunion through dialogue between the Christian churches of East and West moved the Croatian bishop-theologian, although Franic feared that it might not be possible for him to find among Serbian Orthodox clergy in Yugoslavia a partner for the fraternal ecumenical hug. The bishop had worked for nearly four years in the Council's theological and doctrinal preparatory commissions and had attended all the Council's sessions. At 47, the avid churchman came back to his communist-ruled country worrying about the chances for implementation of the Council's ideas. The Croatian prelate was convinced that there was no alternative to the Council's quest for an open and tolerant dialogue with people of different faiths and with those without religious affiliation. The bishop also thought that approaching the communists for a dialogue would be a wise strategy. Although the Council did not abandon the idea of the anticommunist struggle, it urged the faithful to pursue this struggle not by means of 'violent confrontation', but through the means which the incumbent pope has recently described in reflections on the historic Council: 'Christians persisted in trying every avenue of negotiation, in dialogue, and 
witnessing of the truth, appealing to the conscience of the adversary and seeking to reawaken in him a sense of shared human dignity'.

As a church leader, Bishop Franić did not look favourably on zealots. He often had to mitigate conflicts created by militant clerics who sought direct confrontation with the communist regime or rival religions in this multiconfessional country. In Yugoslavia Franić also witnessed militancy emanating from the largest Yugoslav religious institution, the Serbian Orthodox Church, and from ruling communists. As a student at the Pontifical Gregorian University at Rome, in July 1937, the concerned Franic had followed the news about street protests organised by the hierarchy of the Serbian Church which, in order to preserve its status as the official state religion, opposed the ratification of a concordat between the Belgrade regime and the Holy See. When Franić was ordained bishop in 1950 he was several times attacked by a mob during diocesan pastoral visitations. Nonetheless, the Croatian bishop believed that the Council had found a formula according to which the Catholic Church could help reconcile numerous contradictions in communist-ruled Yugoslavia, the Balkan country which brought together six major nationalities, 17 national minorities, three mainstream religions, and over 40 other denominations. Franić knew that relations between the two largest Yugoslav religious institutions, the Serbian Orthodox Church and the Croatian branch of Catholicism, were the key for the success of the Council's ecumenical idea.

\section{Paths of Dialogue}

The Second Vatican Council (1962-65) was the Catholic Church's response to challenges in an era of rapid change. The church could not watch passively the worldwide decline of religion, secularisation in the most advanced countries, atheistic communism, the new wave of nationalism, emerging nations searching for optimal models of development, and global migrations. Among the challenges for the universal church was the start of an 'ecumenical', or global, movement for the unity of Christian churches. The movement had been dominated by American and Western European Evangelicals, at least since the beginning of the century. The Council sought to inaugurate Rome as another ecumenical centre, or, to put it more accurately, to reassert this traditional role of Rome in the history of Christianity. Politically, the new 'Roman ecumenism' was, under the circumstances, conceived as both an accommodation to détente in international politics and the spiritual energiser of the Western European unification. In the context of the rebuilding of Europe, relations between the Church of Rome and the Eastern Orthodox Churches became critically important. The 'ecumenical package' of the Second Vatican Council included the ecumenical decree Unitatis redintegratio, the decree Orientalium ecclesarium on the Uniates (that is, Orthodox Churches under papal authority) and guidelines for the implementation of the Council's decisions on ecumenism. The new ecumenism had a paramount importance for Yugoslavia as the common homeland of twenty million people divided among Serbian Orthodoxy, Croatian and Slovenian Catholicism, and Bosnian Islam. The council urged the Catholic Church and the 'separated brethren' of the Christian East (that is, the Orthodox Churches), as well as Evangelical Christians, to work together towards reunification through renewal of spiritual culture, theological dialogue, common prayer and other forms of cooperation. Another Council initiative, important for the Balkan country with the largest indigenous Muslim community in Europe, was the document Nostra aetate which encouraged dialogue with non-Christians. The third Council document relevant for 
communist Yugoslavia was De dialogo cum non-credentibus.

Unitatis redintegratio encouraged common Catholic-Orthodox prayer, or intercommunio. In January 1966 the Catholic Church in Croatia inaugurated annual interfaith prayers, the so-called 'Octave of Prayer for Christian Unity'. It was Bishop Dr Franic who organised the first joint ecumenical prayer between clergy representing old Yugoslav ethnic rivals: Catholic Croats and Orthodox Serbs. It was not only an encounter of two ethnic nations whose nationalist factions had been in conflict since the foundation of the state in 1918 , but also a spiritual meeting between two formerly rival churches which, in the Council's terms, were to become sister-churches. As the incumbent pope recently reflected on the occasion of the twentieth anniversary of the ecumenical decree, 'ecumenical endeavour of the sister churches of East and West is seeking the rediscovery through prayer and dialogue of the visible unity in perfect and total communion, the unity which is neither absorption nor fusion'. ${ }^{3}$

In preparation for the historic prayer, Bishop Franic visited the Serb Orthodox bishop Stefan (Boca) in the coastal city of Šibenik, trying to win him over to the idea of the joint prayer. Boca remained rather sceptical about, in his words, 'a highly esteemed, but sensitive and perhaps premature move'. ${ }^{4}$ Several weeks later, after consultations with the Serbian Patriarchate in Belgrade, the Serb bishop advised his Catholic counterpart to postpone the prayer until a happier moment. Franic then turned to the local Orthodox archpriest in Split, his old friend Marko Plavša. Plavša agreed to take part in the joint prayer. Franić announced the event over Sunday Mass, despite opposition by his aides who argued that only another bishop or a head of monastic order would be an appropriate partner on such an occasion. The prayer still took place on 25 January 1966. Franic recalled the event in an interview with the author:

It was earlier unthinkable that we Catholics invite the Orthodox to our church except to convert them. Likewise, we Catholics never set foot in a 'schismatic' church. Yet after the Council, it was no longer a schismatic but a sister-church. My old friend Marko and I endeavoured to break the ice. Plavša, representing the Serbian Orthodox Church, read the Gospel in Serbian, pronouncing the Scripture in the ekavian dialect although he is a native of the nearby city of Sinj in Dalmatia and he normally does not speak that way. Yet on this occasion the Serb priest wanted to assert his Serbian identity. At any rate, two churches worshipped together and the congregation applauded several times, which was, then, an unusual practice in churches. In conclusion came the fraternal hug and I saw the faithful deeply moved. ${ }^{5}$

Bishop Franić recorded the historic prayer in his chronicle of diocesan affairs:

Ecumenical prayer in the Cathedral was held on the occasion of the Octave of Prayer for Christian Unity together with the archpriest Marko Plavša as representative of the Orthodox bishop of Dalmatia, and with $\mathrm{Mr}$ Marko Stojanac on behalf of the Orthodox church community in Split. The archpriest Plavša read in the crowded cathedral Eph. 4 1-17 and 13-21, and when finished, gave the bishop a fraternal hug. The congregation was moved; many had tears in their eyes. The archbishop addressed the Orthodox with special words, greeting them as beloved Christian brethren. ${ }^{6}$

The bishop of Split-Makarska was conscious of the symbolic and religious as well as 
the political connotations of the first Serbo-Croat prayer in the history of the Yugoslav peoples. The spontaneous warm response from the Croat congregation was the first postwar symbolic counterattack against the official communist doctrine according to which churches were the immanent source of ethnic and religious hatred. The Serbo-Croatian prayer demonstrated that it was not exclusively the Communist Party which could secure what was officially termed the 'brotherhood and unity' of the Yugoslav peoples. Religion and church, perhaps even more effectively than any political party, could bring diverse people together. According to the Catholic historian Juraj Kolaric, the common prayer in Split was a landmark event in church history, widely received with hope and sympathy, and was a powerful stimulus for many ensuing interfaith activities in Yugoslavia.?

Contrary to Bishop Franić's desire, however, the ecumenical prayer at Split was discontinued. In January 1967 it was cancelled because of Plavša's illness. As Franić recalled later, Plavša, seriously ill, confessed that his bishop, Stefan, had criticised him for naïveté and foolishness. Plavša also received phone threats and angry letters from exile Serbian nationalist organisations. Some cleric zealots called Plavša a traitor to Serbia. Shortly after the historic prayer, the ecumenical pioneer Marko Plavša died of cancer. Dr Franić believed that pressure from Serb Orthodox zealots had aggravated his illness. Franić, who in 1967 became archbishop-metropolitan (among other reasons, because the Holy See appreciated his ecumenical effort), could not carry on the annual ecumenical prayer. Yet on the occasion of the Holy Year of Mary in 1976 Franić welcomed the Orthodox bishop Stefan, accompanied by a delegation of Jews and Bosnian Muslims, in the same cathedral where the first ecumenical prayer had taken place. Meanwhile the archbishop of Split and the local Orthodox clergy inaugurated Christmas and Easter visits to each other's churches. After worship services the clergy of the two largest Yugoslav churches would go together for a walk down the main streets of the town. When one reads reports on these events by communist activists and police, it is clear that local communist leaders were divided between 'liberals' who praised them as invaluable support for the official policy of 'brotherhood and unity' and hardliners who viewed them as another clerical conspiracy aimed at overthrowing the Party, and then turning Serbs and Croats against each other. ${ }^{8}$

The post-Council ecumenical spirit burgeoned and facilitated numerous forms of interfaith cooperation in all parts of the Yugoslav federation of six republics. Clergy and representatives of Catholic, Orthodox and Protestant churches, as well as Jews and Bosnian Muslims, exchanged mutual visits on occasions of religious festivals and main holidays. According to a Yugoslav government expert for interconfessional relations, ecumenical cooperation was especially successful in BosniaHerzegovina, with Catholic, Orthodox and Muslim clergy visiting and greeting one another on religious holidays and local festivals. ${ }^{9}$ For example, on the occasion of the consecration of a newly-built Orthodox church in the Serbian town of Gračanica in Bosnia the local Serb bishop thanked 'our Muslim brethren for generous donations' for the construction of the church. ${ }^{10}$ Likewise, delegations of the Serbian Orthodox Church attended all the major events of the Catholic Church's nine-year jubilee (the Great Novena, 1975-84) entitled 'Thirteen Centuries of Christianity among the Croatian People' ('13 stoljeća kršćanstva u Hrvata'). The Serb clergy were greeted with applause by Catholic faithful at shrines and tabernacles in Croatia and Bosnia. Interestingly enough, the grand jubilee 'Great Novena' had a quintessentially nationalistic content. However, the spirit of the Second Vatican Council affected the jubilee in a positive way, insofar as the Council, with the subsequent papal encyclical 
Populorum progressio (1967) and the Synod of Bishops at Rome (1971), emphasised so-called 'positive' and tolerant nationalism as opposed to intolerance and ethnic hatred. It is noteworthy that the chief architect of the Croatian 'Great Novena' was, again, the ecumenical pioneer Dr Frane Franić. At any rate, between 1965 and 1989 ecumenical activities proliferated. The interfaith prayer in January brought together Catholics, Protestants and some lower Orthodox clergy. In the late 1970s even Muslims joined in. After the groundbreaking 1966 prayer, interfaith vigils were held in several towns in Croatia and also in Vojvodina, Bosnia-Herzegovina, Slovenia and the country's capital Belgrade. In Subotica, Vojvodina, the Catholic Church and the Reformed Church initiated a 'Christian Women's Prayer Movement' in 1975.

The Council also made possible the restoration of diplomatic relations between the Holy See and the communist regime under Josip Broz Tito. Since the mid-1950s the Yugoslav leader had evolved into a world statesman, one of the founders of the movement of nonaligned countries. In that capacity the 'anti-Stalinist' independent national communist thought of bringing the internationally influential Vatican into the movement. The traditionally 'nonaligned' Vatican, at that time looking with considerable interest at the Third World terrae missionis, was not indifferent. Relations between communist Yugoslavia and the Vatican had collapsed in 1953 when the pope elevated the jailed Croatian archbishop Alojzije Stepinac (1899-1960) to the College of Cardinals. Stepinac had been sentenced by the communists on the account of alleged collaboration with the native Croatian fascists, the Ustashas (s. ustaša, pl. 'ustaše'), during the Second World War. After the Council Pope Paul VI and secretary of state Cardinal Casaroli sought rapprochement with Belgrade. Tito welcomed the initiative and, after long negotiations, managed to obtain an agreement largely in accordance with his own terms and conditions. ${ }^{11}$ One of the conditions was that the Catholic Church would not reopen the case of Cardinal Stepinac. Tito also demanded that the church refuse collaboration with exile Croatian political groups, which were meanwhile building the cult of Stepinac as a martyr and hero of the Croatian people. In 1970 Yugoslavia became the only communist country in Europe to maintain full diplomatic relations with the Vatican. Tito, anathematised by Pius XII, was the first communist leader to meet Pope Paul VI.

The Tito regime welcomed the Council's ecumenical initiative, though with a caveat. The communists needed a patriotic attitude from Yugoslavia's mainline churches, as well as cordial relations among the clergy, who always had a strong influence on ethnic relations. Yet the regime was suspicious about the sudden collaboration among religious leaders. Tito and his communists had won the bloody ethnic war in Yugoslavia (1941-45) and portrayed themselves as saviours of the Yugoslav peoples from genocidal massacres carried out by the Croatian Ustashas, Serbian Chetniks (s. četnik) and other nationalistic factions. According to the communist view of Yugoslav history, religion was a reinforcing component of ethnic hatred and accountable for wartime massacres. ${ }^{12}$ In 1945 the Yugoslav People's Assembly passed a law 'prohibiting the spread and incitement of ethnic, religious and racial hatred'. The maintenance of the precarious interethnic equilibrium through the quasi-religious concept of 'brotherhood and unity' (with only a sporadic show of force and repression against ethnic nationalistic opponents) was the major source of the communist regime's legitimacy. Finally, like all communist regimes, the Yugoslav regime was hostile toward religion and suspicious about what seemed like 'plotting against the common enemy'. Small wonder that the regime was in a quandary over to what extent to support the post-Council interfaith dialogue. Cognisant of the regime's suspicion, the ecumenical pioneer Archbishop Franic 
argued in a 1973 interview with a secular newspaper that 'ecumenism should be critically important for our state and society, because it operates as an effective instrument for promoting tolerance, better understanding and a spirit of liberty among Christians and non-Christians and among peoples of different nationalities in this society'. ${ }^{13}$

While the grass-roots ecumenism described above was continuing, the Yugoslav ecumenical movement was also making noticeable progress through academic symposia organised by theological schools. Since 1960 the Catholic Theological Faculty in Zagreb had been holding annual theological-pastoral weeks open to theologians of all denominations. In 1964 theologians and seminarians from religious schools in Zagreb, Ljubljana and Belgrade held their first informal ecumenical interfaculty symposium. 'Free of hierarchical rigidity, theologians could effectively advance ecumenical ideas', wrote an ecumenical expert. ${ }^{14}$ In 1974 the second-largest city of Slovenia, Maribor, hosted the first official ecumenical 'Interfaculty Symposium' with the three above-mentioned schools attending. Representatives of other schools, Catholic and Protestant, came as observers. The second interfaculty ecumenical symposium took place in Lovran, Croatia, in 1976. The Orthodox Theological Faculty in Belgrade hosted the third ecumenical symposium at Arandjelovac, Serbia, in 1978. The meetings were held every two years until 1990. As soon as they were founded, the Macedonian Orthodox Church's theological school in Skopje (opened in 1977) and the Islamic theological school in Sarajevo (opened in 1980) took part in the ecumenical symposia.

Meanwhile the ecumenical movement among lower clergy and local interfaith cooperation had been expanding. The major ecumenical centre in Croatia was Djakovo, the diocesan seat of the Croatian-Austrian ecumenical Bishop Josip Juraj Strossmayer (1815-1905), the founder of the Yugoslav Academy of Sciences and Arts (today the Croatian Academy). Local interfaith meetings were particularly frequent and cordial in traditionally tolerant regions such as Istria, coastal Dalmatia and Slavonia, but also in central and northern Bosnia where Catholics, Orthodox and Muslims lived side by side in mixed communities. Ecumenical activities were especially popular and successful in the autonomous province of Vojvodina, a microcosm of nationalities and home of more than 20 independent Christian denominations (in addition to the two major national Christian churches). To summarise, then: with stimulus 'from above' by the Second Vatican Council, interfaith cooperation in Yugoslavia was developing simultaneously as diplomacy of clerical elites and as a grass-roots movement.

\section{Unhealthy Memory or a Cry for Justice?}

The hierarchies of the two major Yugoslav churches sought to develop a separate ecumenical agenda at the highest level. Again, it was the Catholic party which made the first step, inviting Orthodox Serb leaders for dialogue and cooperation. The only Croatian cardinal, Franjo Seper, then the archbishop of Zagreb and occupying a high post in the Vatican, approached the patriarch of Serbia in the hope of establishing regular summit meetings between the two churches. On the occasion of the ecumenical prayer week in January 1967 Cardinal Seper wrote a letter to Patriarch German (Djorić). The cardinal proposed top-level meetings as a joint testimony to restored friendship along with cooperation on a number of specific issues such as, for instance, the problem of mixed marriages, preservation of the cultural heritage, religious instruction, the social status of clergy and relations with the state. The patri- 
arch responded in a kind tone, but the cardinal's concrete proposals were ignored. The patriarch did not even agree to meet the cardinal. Writing on behalf of the Holy Synod of the Serbian Orthodox Church, German indicated that the Serbian Orthodox Church might be prepared, at that point, to take part in dialogue only through a joint theological commission.

The patriarch, who otherwise had a knack for diplomacy and intimately admired Tito's policy of nonalignment, was in a quandary. The Serbian Church has by tradition been independent-minded. The church's founder, St Sava, was a statesman and diplomat whose cult entailed emphasis on the church's autonomy from both Rome and Byzantium. At the time of the Second Vatican Council German's foreign policy priorities involved upgrading relations with the Russian Orthodox Church, the Ecumenical Patriarchate at Phanar (Istanbul) and other Orthodox churches. After the 1955 Tito-Khrushchev rapprochement the Serbian Church was able to restore traditional friendship with the Moscow Patriarchate. Regarding western churches that is, Protestants and the Vatican - the head of the Serbian Church sought to emulate Tito, which meant playing the two off against each other, and obtaining various concessions and financial aid while preserving full autonomy for the Serbian Church. To be sure, the Serbian Church had collaborated with some Protestant ecumenical associations since the 1920 s and had attended all major ecumenical meetings after the Second World War (while maintaining no ties with the Vatican), but until 1965 vacillated regarding repeated Protestant invitations to join any ecumenical association officially.

Yet the ecumenical initiative launched by the Second Vatican Council required a response. It was not just a friendly move but also a form of pressure on the Church of Serbia. German could continue to vacillate (like Tito in the Cold War arena), or take sides. In order to buy time, he invoked the not very felicitous tradition in relations between Rome and Constantinople and proposed theological debates as the dominant vehicle for interfaith relations. The head of the Serbian Orthodox Church presumably thought that theologians would break the ice and buy time, after which he himself would take over the diplomacy between Serbia and the Vatican. To be more explicit: the patriarch, like Tito earlier, while negotiating the restoration of diplomatic relations, sought negotiations with the pope rather than with the Croatian episcopate.

Nevertheless, German was well aware that the two major Yugoslav Churches had to cooperate. The heartland of the country was virtually indivisible and the two ethnic relatives had too much in common to afford the risk of behaving like sects or hostile neighbours. And after all, the two churches and ethnic groups shared two enemies: the communists, who despite the liberalisation of the 1960 s remained hostile toward religion; and the traditional perceived Muslim challenge from Bosnia and Kosovo: in the latter, worryingly for the Christian churches, the population was recording the highest birthrate in Europe.

It was nevertheless difficult for German to fraternise with Croatian Catholic church leaders. During the Second World War a majority of Croatian clergy had sided with the Ustasha fascists. In the late 1950s exile Serb nationalist organisations and branches of the Serbian Church in the United States and Canada had accused German of collaborating with the Tito regime. ${ }^{15}$ If the patriarch now took part in summit meetings with Croatian church leaders, certain groups would accuse him of collaborating not only with the communists but also with accomplices in what the Serbian Orthodox Church considered to be genocide against the Serbs and the Serbian Church. The latter had faced annihilation in the Ustasha state. The Croatian 
fascists killed 217 out of the prewar total of 577 Serbian priests in Croatia and Bosnia, including three bishops, expelled 344 to Serbia and destroyed around 400 Serbian places of worship. ${ }^{16}$

The meeting of the Holy Synod which discussed the 1967 ecumenical initiative by Cardinal Seper encountered a difficult task. The latter was after all the successor to the wartime archbishop of Zagreb, Alojzije Stepinac, who in the eyes of the Serbian Church was a pro-fascist and war criminal supportive of the Ustasha regime. Some members of the Holy Synod argued that official contacts with the Croatian episcopate would not be possible until Croat church leaders addressed the issue of the Ustasha massacres, the destruction of Orthodox churches during the Second World War and the forcible conversion of the Orthodox, and released a statement of repentance with a plea for forgiveness addressed to the Serbian Church and the Serbian people. As a precautionary measure in view of probable reaction from the regime the Synod concluded that this precondition would not be stated explicitly but only inferred. Yet the apology issue was occasionally raised in articles in the church press, inferred in some sermons and discussed among theologians. In conversation with me in 1990 the dean of the Catholic Theological Faculty in Zagreb, Tomislav Šagi-Bunić, who was Cardinal Šeper's adviser, told me that the Orthodox used innuendo rather than making explicit requests for an apology. By contrast, theologians freely debated the issue at the meetings of theological schools although it was not officially part of the agenda. ${ }^{17}$

In the exile press (both Serbian and Croatian) in the United States, Canada and Australia numerous articles were published dealing with the apology issue and routinely attacking ecumenism. In 1962 the Bishops' Council of the Serbian Orthodox Church finally responded to initiatives launched in the 1950 s by the exiled bishop Nikolaj Velimirović from Libertyville, Illinois (1888-1956), who argued that the Patriarchate must sever contact both with the communists (until they halted discrimination against the church and confessed their crimes) and with Croat Catholics (until they issued official apologies to the Serbian Church and the Serbian people for persecution and genocide during the Second World War). In the meantime, Velimirovic proposed that the Serbian Church commemorate the victims of the Croatian and communist crimes across the country at the sites of Serbian martyrdom. The Serbian Bishops' Council inaugurated the cult of martyrs of the Second World War, and designated the site where once stood the Ustasha concentration camp of Jasenovac in northern Croatia as a shrine to the new martyrs. German's 1962 move was a concession to zealots, especially those in exile. The patriarch sought to avert a looming schism in the Serbian Church's North American branch.

As an example of what the Serbian Church could expect from the Croatian episcopate and the Vatican, Serbian clergy and theologians referred to the Catholic bishop of Banja Luka (Bosnia-Herzegovina), Dr Alfred Pichler. On 20 December 1963 this Bosnian churchman released a Christmas message which read as follows:

It was precisely in this country, that, in the past war, many of our brothers of the Orthodox faith were killed because they were Orthodox Christians. Those who killed them called themselves Catholics. And those Catholics killed other people, also Christians, because they were not Croats and Catholics. We painfully admit the terrible self-deceit of those strayed people and we beg our brothers of the Orthodox faith to forgive us, just as Christ had forgiven us all from the cross. At the same time, we forgive everyone, if they perhaps hated us or did us injustice. ${ }^{18}$ 
As Serbian churchmen applauded Pichler's message, many Croatian Catholic leaders saw Pichler as politically gullible. In their view he was unaware of the aim of those pursuing Great Serbian politics: imposing upon the Croats a sense of collective guilt which would make it near-impossible to awaken Croat national pride, mobilise the masses and achieve a religious renaissance among the Croats, as craved by the Catholic Church in Croatia. Croatian bishops and theologians opposed any unilateral act of repentance, arguing that ethnic massacres in Yugoslavia had not been exclusively the work of the Croatian nationalist Ustashas. The Serb guerrilla Chetniks and the communists had committed massive crimes against Croats and Muslims. Catholic theologians also argued that only secular, democratically-elected political leaders were entitled to issue political apologies on behalf of a particular nation. Finally, as dean S̆agi-Bunić told me in the 1990 interview cited earlier, the Catholic party in the quarrel accused the Serbian Church of seeking the role of 'Lord of history' by passing judgments on recent and controversial historical events.

In the meantime the Catholic Church pursued its initiative for a summit meeting of the major Yugoslav churches. The Archbishop of Zagreb, Cardinal Seper, then also prefect of the Sacred Congregation for the Doctrine of the Faith, visited Patriarch German in Belgrade. Another high official in the curia, Cardinal O'Bea, the architect of Unitatis redintegratio and the chairman of the pontifical secretariat for Christian unity, came to Belgrade for talks with the patriarch of Serbia. Apparently the Vatican was wooing the Serbian Church, seeking rapprochement. Finally, Seper and German agreed to meet on 26 June 1968. This brief meeting, held at the historic seat of the Serb Metropolitanate at Srijemski Karlovci on the Serbo-Croatian border, was the first in a series of future annual top-level meetings of the churches. Yet there was never an 'agenda' on the table, because the Serbian church hierarchy refused to discuss any specific issue until the Croats apologised for the Ustasha genocide. The 1968 meeting was praised by some liberal officials of the communist regime as well as by the Vatican and recorded with favourable comment in the domestic and foreign church and secular press. Needless to say, the exile press, both Serbian and Croatian, found a common language in describing the meeting in terms of 'treason', 'capitulation before godless communism' and so forth.

A confidential federal report released in 1969 by the commission for religious affairs affiliated to the Yugoslav Federal Executive Council describes the interfaith dialogue as follows:

Ecumenical currents in our country continue through various contacts among clergy and believers of different faiths. Overall, the practice is positive. The clerical cooperation is a counterweight to the traditional religious intolerance and earlier quarrels among the high clergy. When priests and bishops of different religious organizations attend public events and celebrations together (which has been frequently observed, especially in Bosnia-Herzegovina) it creates a favorable political climate. However, the ecumenical ideas are coming into a conflict with conservative orientation inside certain church circles. Thus, top leaders in the Serbian Orthodox Church prohibit its clergy to take part in the interfaith dialogue with Catholic priests. Some Serb church leaders insist that the Catholic Church, as a precondition for the dialogue, condemns publicly Second World War Ustasha crimes against the Serb-Orthodox population in Croatia and Bosnia-Herzegovina. The Catholics say that the Orthodox Church must apologize for the Chetnik massacres over Croats and 
Muslims. Finally, it is our assessment, that mistrust and intolerance between churches is so deeply rooted that ecumenical cooperation and religious leaders' effort aimed at building an ideological alliance against organized socialist political forces, are not likely to succeed. ${ }^{19}$

While religious leaders played politics with the apology issue, another obstacle to more successful interfaith cooperation in communist Yugoslavia was the influence of some radical antiecumenical theologians. One of the most influential in the Orthodox Church was the Serb monk, former university professor and archimandrite Justin Popović, whom the Tito regime sentenced to a long prison term for anticommunist propaganda. In 1974 in Greece Popović published a study on ecumenism in which he condemned both factions of the global ecumenical movement: the so-called 'Geneva ecumenism' dominated by American Evangelicals and the 'Roman ecumenism' launched by the Second Vatican Council. ${ }^{20}$ Popovic designated the Orthodox Church as the only true and credible spiritual force capable of accomplishing the ideal of Christian unity (through the Orthodox Church). Another influential antiecumenical theologian in the Serbian Church was the exile bishop Nikolaj Velimirović. By contrast, in the Croatian branch of the Catholic Church there were quite a few ecumenical enthusiasts. In fact, only two prominent Croatian churchmen could possibly be designated, not as antiecumenical, but as extremely suspicious of the Serbian Orthodox Church. These were the archbishop of Zagreb, Franjo Kuharić, later cardinal, and the editor-in-chief of the leading Croatian Catholic newspaper Glas koncila, Živko Kustić. The wartime church leader Cardinal Alojzije Stepinac was a role model for both Kuharić and Kustić.

In 1975 the leading Serbian theologian archimandrite Atanasije Jevtić, then professor at the Serbian Orthodox Theological Faculty in Belgrade, argued at an ecumenical conference against interfaith prayers. Jevtic was a pupil of the antiecumenical theologian Justin Popović. Theologians in the Orthodox Church, with few exceptions, shared Jevtić's views. The distinguished professor of the Belgrade Orthodox Theological Faculty Dimitrije Bogdanović wrote in 1971 as follows:

I am afraid that the Roman Catholic Church's strategy of dialogue is but another way to achieve the reassertion and rejuvenation of Roman Catholicism as the leading social and political force in the world. That is why we Orthodox cannot espouse this ecumenical dialogue: to do so would be to help make room for political manoeuvring aimed at placing one religious organisation above the others, turning it into a centre of social and political power and promoting it to the status of equal partner with the state. If one religious organisation acquires for itself such a decisive influence in political life it will soon demand a special status and privileges other churches do not ask for themselves. That would disturb the religious equilibrium in our multiconfessional society, with possible serious political implications. Consequently, the fundamental precondition for a serious and open dialogue will be that the Roman Catholic Church as well as other churches become thoroughly apolitical. ${ }^{21}$

Bogdanović's article was published in the newsletter of the patriotic pro-regime Orthodox clerical association Udruženje pravoslavnog sveštenstva in order to influence the readers, most of whom had espoused Catholic ecumenism, viewing it as an equivalent to the Titoist 'brotherhood and unity'. Both Jetvić and Bogdanović spearheaded a theological counterattack in response to the proecumenical spirit 
which had been growing since the late 1960s among the rank and file of the Serbian Orthodox Church. Members of the Udruženje criticised Jetvić's views and praised council ecumenism as an instrument for advancing the 'brotherhood and unity' of the Yugoslav peoples. For example, Father Jovan Nikolić, a parish priest in Zagreb (Croatia), regularly took part in common prayers and vigils during the annual Octave of Prayer for Christian Unity. Nikolić also wrote articles in support of ecumenical cooperation. Archimandrite Jetvić attacked Nikolić in the clerical association's newsletter, accusing him of lacking theological background and of being influenced by Roman Catholic ecclesiology. ${ }^{22}$ Views similar to Nikolić's were also expressed by one of few proecumenical Serb theologians who attended theological conferences with Catholic theologians, Dimitrije Dimitrijevic, professor at the Orthodox Theological Faculty in Belgrade. In 1976 Dimitrijević wrote a series of polemical articles on ecumenism, criticising Jetvić. He argued that a 'dialogue of love' should be given priority over 'theological intricacies, because the primacy of love over doctrine means the primacy of God'. ${ }^{23}$

By the end of the 1970s antiecumenical feeling was growing in the Serbian Church. In 1978 the Serbian Church boycotted the conference of the joint international commission for theological dialogue between the Roman Catholic and Orthodox Churches which took place at the centre of the Ecumenical Patriarchate in Chambesy, Switzerland. The Serbian Church opposed this conference's call for common prayer as the instrument of interfaith cooperation. The antiecumenical spirit in the Serbian Church was also linked with the cult of the exiled bishop Velimirovic who died in 1956. Velimirović's followers were proposing that the Bishops' Council make Velimirović a saint. In the meantime, Croatian clergy and Ustashas in exile were campaigning in the Vatican for the sainthood of the anticommunist and antiSerbian cardinal Stepinac.

\section{Forgive but not Forget}

From 1975 to 1984 the Croatian branch of the Catholic Church staged a grandiose nine-year jubilee in honour of the conversion of the Croats to Christianity. The jubilee involved massive liturgical events and pilgrimages with hundreds and thousands of faithful in attendance. Apparently Croatian Catholicism was flexing its muscles, and both the ruling communists and the Serbian Orthodox Church showed signs of growing anxiety. Meanwhile Croatian Catholic parishes and missions established among Croatian migrant workers and ethnic communities in Western Europe and overseas had mushroomed. Financial aid in hard currency was pouring into the church in the homeland. Although the relatively impoverished Serbian Orthodox Church envied its Croat rival, the patriarch-diplomat German tried to keep pace with the competitor. He spent a lot of time cultivating church foreign relations, an area in which independent or autocephalous Eastern Orthodox churches are frequently especially active. Like Tito, the patriarch of Serbia was a world traveller. He was eight times in Moscow; he travelled three times to Jerusalem, Greece, Cyprus, Turkey and Egypt; he visited all the national Orthodox Churches and exchanged visits with the ecumenical patriarch of Constantinople and the archbishop of Canterbury. Tito appreciated German's foreign policy efforts, especially those directed towards nonaligned countries. Once he even made available to German a state-owned aircraft which the patriarch used for 35 days during his travels to the Middle East. German met Patriarch Pimen of the Russian Orthodox Church four times during the 1970 s, the period of Tito-Brezhnev cooperation and the most stable period in 
Yugoslav-Soviet relations. In 1965 the Serbian Orthodox Church joined the Genevabased World Council of Churches (WCC), and in 1968 the patriarch of Serbia was elected one of its six chairmen. The Serbian Church was the last among Orthodox churches to join this international ecumenical association. Patriarch German was criticised by the Serbian zealots for cooperating with an organisation dominated by 'schismatic' Protestants. Yet the Serbian Patriarchate received generous financial support from the WCC: 'the tremendous help ... had kept pouring in from Geneva ... in 1958: $\$ 18,558$; in 1959: $\$ 128,749$; in 1960 : $\$ 9,939,189$; in $1961: \$ 5,960,042 \ldots{ }^{24}$ The Serbian Orthodox Church had not altogether rejected the ecumenical initiative of the Second Vatican Council, but by joining the WCC nevertheless intended to send a message to the pope that relations between the Vatican and the independent-minded national Church of the Serbs would not develop in accordance with papal terms and conditions.

German was a moderate and canny church leader. Nevertheless he was compelled by two burning issues in Yugoslav politics in the 1980s to make concessions to a growing number of zealots in the church.

The first issue was the escalation of nationalism and separatism among the largest non-Slavic group in Yugoslavia, the ethnic Albanians in the province of Kosovo. Kosovo, with more than a thousand churches and monasteries built by Serbian rulers in the thirteenth and fourteenth centuries, including the seat of the first patriarch of Serbia at Peć, was critically important to the Serbian Church. In the mid-1980s Serbian churchmen began referring to Kosovo as a 'Serbian Jerusalem'. In response to massive Albanian demonstrations in 1981 the Church of Serbia called for the defence of the cradle of the nation. Yet the Croatian Church press, Radio Vatican and some Catholic churchmen expressed support for the Albanian quest for autonomy in Kosovo. At about the same time the Orthodox Church of Macedonia seceded from the Belgrade Patriarchate and obtained support from the Vatican. In consequence, relations between the two main Yugoslav churches began rapidly worsening.

The second, no less poignant political issue for the Serbian Orthodox Church was a campaign for the sanctification and vindication of the wartime archbishop of Zagreb, Alojzije Stepinac, who was officially considered a collaborator with the Ustasha regime. In 1979 Archbishop Franjo Kuharić inaugurated annual commemorations of Cardinal Stepinac at Zagreb Cathedral. Kuharić, who in 1983 was made a cardinal in papal acknowledgment of the successful accomplishment of the 'Great Novena', portrayed Stepinac in his sermons as a Christian martyr. He argued that Stepinac had been falsely accused by the communists. According to church sources Stepinac had protested against Ustasha crimes and even allegedly rescued many Serbs and Jews from Ustasha persecution. Kuharić also cited arguments put forward by Croatian nationalistic historians, notably Franjo Tudjman, according to which the total number of Ustasha victims had been grossly exaggerated by the communists and Serb nationalists in order to discredit the whole Croatian people and keep Croatian nationalism in check. Serb historians would cite the number of around a million Serb victims in the Jasenovac camp alone, let alone other Ustasha camps, whereas Tudjman came up with the figure of a maximum of 40,000 for the Jasenovac camp. ${ }^{25}$ In 1981 the archbishop of Zagreb submitted the Stepinac case to the Vatican's Congregation for the Causes of Saints. The Curia routinely initiated the procedure $d e$ virtutibus, which includes the study of the candidate's life and demeanour, in order to determine whether, as the proposal argued, the candidate had lived a life strictly according to Christian norms, thereby setting an example for others. When the Great Novena was successfully concluded in 1984 the Stepinac case was elevated to the 
stage de martyro, focusing on the candidate's struggle against communism and years in jail.

The Serbian Orthodox Church, which had consecrated the martyrdom of the Serbs during the Second World War as a national patriotic cult and which referred to Ustasha crimes as genocide, decided to deliver a strong message to the increasingly nationalistic Croatian Catholic Church. The occasion was carefully chosen: the socalled 'National Eucharistic Congress of the Church of the Croatian People' ('Nacionalni euharistijski kongress'), the final ceremony of the Croat nine-year church and national jubilee of 'Thirteen Centuries of Christianity among the Croatian People'. ${ }^{26}$ On 2 September 1994 the Serbian Church convened 20,000 faithful at the site of the Second World War concentration camp of Jasenovac in northern Croatia. The occasion was the consecration of the new Jasenovac parish church of St John the Baptist, destroyed by Croat fascists in 1941. In fact, it was the first official postwar commemoration by the Serbian Church of the victims of Jasenovac, and it took place with the consent and financial support of the communist regime in Croatia, only a week before the final ceremony of the Catholic Great Novena. The aim of the Jasenovac commemoration was to raise awareness among Serbian people that they had been victims of a genocide nearly equal to the Holocaust and at the same time to remind the Croats and their clergy of the shame of the Ustasha crimes of genocide which still remained without appropriate condemnation and public repentance. In response to the Great Novena, which included a symbolic and ritual recapitulation of Croatian church and national history, the Orthodox Church warned its archrival that the history of the Croats contained not only bright moments celebrated by the Great Novena, but also dark spots which the Catholic episcopate was seeking to delete from memory.

The Jasenovac commemoration, in the words of the Orthodox metropolitan of Zagreb-Ljubljana, Jovan Pavlović, was the Serbian Orthodox Church's response to

attempts that seek to obliterate the traces of Jasenovac, to reduce the total immense number of victims, to deny the crime and forget it! We cannot, and shall not, ever forget the sufferings of the innocent children in Jasenovac. ... A too easy forgetfulness of evil means that it could be repeated. ${ }^{27}$

Patriarch German echoed the metropolitan in his Jasenovac sermon. At Sunday liturgy on 2 September 1984 the patriarch of Serbia drew parallels between Jasenovac and Jerusalem (Golgotha), and between Jasenovac and the Nazi concentration camps at Auschwitz, Mauthausen and Dachau. The patriarch stressed that those who had committed the crimes at Jasenovac were Christians who killed and tortured other Christians, in the belief that thereby they had done patriotic service for their nation. He called on the Serbs to live in peace with other nationalities in the common Yugoslav state, but in an exhortation later widely quoted added:

Brothers, we have to forgive, because such is the Gospel's commandment - but we cannot forget. Let the great-grand sons of our great-grand sons know that this enormous concrete flower on the field of Jasenovac is the witness of madness, which must never take place again. ${ }^{28}$

The chairman of the Bishops' Conference of Yugoslavia, Cardinal Kuharić, was invited to attend the Jasenovac commemoration, but excused himself and sent the auxiliary bishop of Zagreb, Mgr Djuro Kokša. (Bosnian Muslim religious leaders were also in attendance at Jasenovac, as well as Baptists, Evangelicals and Jews.) 
After the Jasenovac liturgy the state television and press reported the patriarch's sermon, and praised German's appeal for peaceful coexistence among Serbs and Croats. Some communist leaders denounced the idea of forgiveness and the appropriation by church leaders of the right to speak on behalf of the nationalities. Catholic leaders were concerned and embittered but not discouraged. The National Eucharistic Congress proceeded, and perhaps naturally took the form of a response to what most Croatian prelates perceived as a slap in the face of Croatian Catholicism delivered by the Serbian Church. On 8 September 1984, at the Croatian national shrine of Marija Bistrica, more than 400,000 people took part in the largest religious convention in the history of Yugoslavia. The convention demanded that the regime lift all restrictions on religious activities and review the case of Cardinal Stepinac. In response, the Serbian Church continued to organise commemorations of what was now commonly being referred to as genocide against the Serbian people. Commemorations of Serbian victims in the Second World War expanded into Bosnia-Herzegovina and reached a pinnacle in the prewar years 1990-91. The ecumenical pioneer Franic expressed his concern over the Jasenovac challenge in his Christmas epistle released in December 1984. Franić, then the archbishop-metropolitan of Dalmatia, wrote as follows:

Also, beware of the peril of unhealthy memories. Some are saying these days: 'We forgive, but we cannot forget'. The worst of all is when this is said by church leaders. Retaining unhealthy memories, and repeatedly recalling to our consciousness old evils and injuries we have suffered, breeds hatred in people's hearts, and such people are only awaiting an opportunity for revenge..$^{29}$

The Orthodox Church, however, had a profound view on the role of memory. As we have just seen, Patriarch German and Metropolitan Jovan were arguing that forgetting past genocide carries the risk of repeating it. The Serbian Church held that it was its sacred duty to commemorate what it viewed as genocide and expected from the Catholic Church that it would show remorse and apologise. Speculation in the church and secular press for months before the National Eucharistic Congress about the possibility of a papal visit to Yugoslavia gave hope to some in the Serbian Church that the Slavic pope would lead a prayer of repentance. Pope John Paul II made several attempts in 1983 and 1984 to arrange a visit to Yugoslavia with the Belgrade government. In 1981 he had received an official invitation from a member of the federal presidency, Cvijetin Mijatović, during the latter's visit to the Vatican. In 1983 private bilateral diplomatic talks were held and the issue of a papal visit to Jasenovac was discussed. At the same time the country was getting ready for the Sarajevo Winter Olympic Games scheduled for February 1984 and the regime was making every effort to maintain a good image in the eyes of the West. Yugoslav negotiators discussing the papal visit pretended that it was only a matter of protocol. A number of sensitive topics were presenting themselves, however, such as the existence of restrictive laws on religious institutions, relations between Croatian Catholicism and Serbian Orthodoxy, the politics of the Vatican concerning the Kosovo crisis and papal support for the Macedonian church schism. According to diplomatic sources, the pope wanted to meet the patriarch of the Serbian Orthodox Church and even to pray at Jasenovac..$^{30}$ However, the post-Tito ruling elite in Belgrade was incapable of reaching agreement on such a sensitive issue as a papal visit, particularly at a time of an increasingly vocal anti-Catholic and anti-Croatian campaign in the Serbian press and among Serbian historians. Serbian nationalist euphoria, which would lead in 
1987 to the ascent to power of Slobodan Milošević, was gaining momentum. The epicentre was in Kosovo and the headquarters of the nationalist mobilisation was in Belgrade. Meanwhile between 1981 and 1984 a number of Catholic priests were jailed for nationalist agitation in Croatia and in Bosnia and Herzegovina. Talks about a papal visit were suspended in May 1984; according to a federal government press release, the visit was postponed and would occur when 'the circumstances become favourable for both parties'. ${ }^{31}$

In the Serbian Orthodox Church the Patriarchate and the Holy Synod were frustrated because, allegedly, nobody had asked their opinion about the papal visit, although in fact the chief secretary of the federal commission for relations with religious communities had discussed the issue with several Serbian church dignitaries. ${ }^{32}$ In the meantime, books critical of the Vatican were being published in substantial numbers in Belgrade. Some Serb historians later argued that the Vatican had rejected the Serbian Church's 'initiative for reconciliation' of 1984. According to Milan Bulajić, in September 1984 the Catholic Church missed the opportunity to condemn Ustasha crimes at the very site where the worst massacres had occurred. Bulajic implied that had the pope come and begged the Serbian people and the Serbian Church for forgiveness the Yugoslav crisis might have been mitigated. 'The opportunity to accept the offered hand of reconciliation was not taken advantage of', concluded Bulajić. ${ }^{33} \mathrm{He}$ even asserted that the Vatican actually desired the disintegration of the Yugoslav Federation of six republics, and echoed mainstream Serbian historiography which argued that the Vatican was historically predisposed against a strong Slavic state with an Orthodox majority in this part of the Balkans. ${ }^{34}$

Instead of issuing a unilateral apology, in 1984 the Catholic episcopate sent the Patriarchate a letter, quoted by Bulajić, which contained a general condemnation of 'all evildoings committed against anyone by any son of the Croatian nation' and demanded in return 'similar condemnation for crimes committed against Croats by Serb nationalist Chetniks and the predominantly Serbian Partisans' ${ }^{35}$ The Serbian Church did not find the letter satisfactory in terms of the idea of Catholic church repentance for Croatian crimes of genocide. According to the Orthodox Church, the Vatican and the Croatian episcopate posed the major obstacle to rapprochement of the churches insofar as they refused to repent and apologise. Had the Catholics done this, goes the Serb argument, the Serbian Church would have agreed to negotiations on specific issues, and the rapprochement would have become feasible. This is allegedly why although Serbian church leaders were taking part in summit meetings they were ignoring repeated calls from the Yugoslav Bishops' Conference to set up a combined working team to resolve concrete problems and upgrade bilateral cooperation. In the eyes of the Serbian church leaders work on concrete problems would only divert attention from the crucial genocide issue.

The Yugoslav Bishops' Conference wrote to the Serbian patriarch in 1982, in 1985 and again in 1989 proposing the establishment of a joint commission and talks on mutual relations. In May 1989 Cardinal Kuharić wrote to Patriarch German to inquire about the continuation of ecumenical cooperation. In response the Serb episcopate, then meeting in its regular spring session at the Patriarchate, composed a long letter to the Croatian bishops and addressed it to the chairman of the Yugoslav Bishops' Conference Cardinal Kuharić. In June 1989 Kuharić received the letter, entitled 'the preconditions for ecumenical dialogue'. On the Stepinac controversy, the Serbian church leaders wrote: 'It is an astounding and horrible fact that the Roman Catholic church hierarchy led by the late Archbishop Stepinac, who was also the military vicar of the Ustasha army, could agree to collaborate with the Ustasha 
regime at times of widespread violence and fear of biological extinction. ${ }^{36}$

The Serbian episcopal letter to the Catholic Church had arrived at a time of growing nationalism in Serbia emanating from the worsening crisis in Kosovo. AntiCatholicism as well as hatred against Muslims were swamping Serbia. In a 1987 interview (published in 1990) Patriarch German said: 'had it not been for the Serbian Holocaust in the Independent State of Croatia (in the Second World War), I believe that Stepinac would never have been becoming a saint'. ${ }^{37}$ In 1989 the Balkan correspondent for the British daily newspaper The Independent wrote that 'attacks on the pope from the Serbian Orthodox Church and the Belgrade media are as popular as in Protestant Belfast' ${ }^{38}$ From the time of the ascent to power of the communist-turnednationalist Slobodan Milošević in 1987 militant Serbian nationalism began emanating from the state-run media and induced similar nationalist responses in Slovenia, Croatia and Bosnia. After mobilising hundreds of thousands of faithful through massive religious jubilees, festivals and commemorations, from the Croatian Great Novena (1975-84) to the Serbian jubilee of the 600th anniversary of the Battle of Kosovo (1989), religious institutions supported ethnic nationalists during the first multiparty elections in 1989-90.

According to the Serbian episcopal letter, the most serious obstacle to the continuation of ecumenical dialogue was the Catholic Church's minimising of the proportions and gravity of Ustasha crimes. The Serbian bishops underscored the fact that since 1955 no Catholic bishop, except the late Mgr Alfred Pichler, had ever expressed remorse for the suffering of the Serbian Church and people during the Second World War. On the contrary, the letter argued, 'a tendency toward minimising the crimes and not telling the truth about the tragic fate of the Serbian Church and people can be observed in the Catholic Church especially in the editorial policy of Glas koncila and public statements by some bishops including Cardinal Kuharic.' The Serbian Church demanded 'not penance for somebody else's crimes, but restraint from further insults'. Furthermore, the Serbian Church complained about the new language policy introduced by the new postcommunist Croatian regime, about alleged Catholic support for the secessionist Macedonian Orthodox Church, about the fact that the Catholic Church had not addressed the Kosovo issue as a serious problem and had even backed Albanian rebellion, and about alleged antiecumenical statements issued by Mgr Kolarić, secretary for ecumenism of the Bishops' Conference. ${ }^{39}$

In its concluding paragraph, the Serb episcopal letter indicated that the Orthodox episcopate was still hoping for some kind of eleventh-hour rapprochement with the Catholic Church, provided the other party accepted the Orthodox Church's 'preconditions for the continuation of the ecumenical dialogue'. Some subsequent public statements issued by Orthodox church dignitaries mirrored Serbian church leaders' hopes that such last-ditch reconciliation might be possible, but as far as the zealots were concerned, they preferred partition and resettlement of population. For example, the influential theologian Bishop Irinej (Bulović) stated in an interview in May 1990 that if the pope still wanted to visit Yugoslavia he must come to Jasenovac together with the Catholic episcopate in order to perform 'an act of repentance, not merely a verbal condemnation of the crimes, and to promise that such a crime will never happen again' ${ }^{40}$ In contrast to Bishop Irinej, the metropolitan of Montenegro, Amfilohije, did not have illusions about rapprochement. This churchman thought about partition of the country between the three founding Yugoslav ethnic nations. In an interview for the Serbian-language Kosovo newspaper Jedinstvo in June 1990 Amfilohije stated: 
There cannot be reconciliation over the graves of innocents. There will be no reconciliation until the Croatian people explicitly renounce evil. ... Today we Serbs are all determined to build a country of our own. At the same time, we must respect the centuries-old desires of our brethren Roman Catholic Croats and Slovenes to establish their national states. ${ }^{41}$

The Yugoslav Bishops' Conference convened at Zagreb, Croatia, on 12 November 1990 to compose its official response to the Serbian patriarch and hierarchy. The Catholic letter implied that the Orthodox Church might not really want the continuation of ecumenical dialogue leading toward the desired ideal of rapprochement between the two sister churches. Rather, as Cardinal Kuharic wrote on behalf of the Catholic Church, 'this is politics, not ecumenical dialogue; such a dialogue better serves certain political ends than it serves ecumenism' ${ }^{42}$ In defence of Stepinac, the cardinal wrote: "the fact is overlooked that the Catholic Church condemned wartime crimes through Archbishop Stepinac'; and he went on to quote one of many similar protests addressed to the Croatian regime by Stepinac: 'the whole Jasenovac camp is a shameful stain on the Independent State of Croatia'. ${ }^{43}$

The Bishops' Council of the Serbian Church held an emergency session in November 1990 . The session elected a new patriarch and officially commenced the commemoration of the 50th anniversary of the beginning of the Second World War and the suffering of the Serbs and the Serbian Church during the War. The Council released a statement on ecumenical relations with the Roman Catholic Church, which reads in part:

Having received a long-awaited response from the Yugoslav Bishops' Conference, this Council declares with deep regret that an intolerant attitude on the part of some Catholic clerics and Catholic intelligentsia in Yugoslavia toward the Orthodox Church, especially toward the Serbian Church, has brought ecumenical relations in our country almost to an impasse. Nevertheless, this Council remains open for fraternal dialogue and will do anything it can to improve the climate of interchurch relations. ${ }^{44}$

By that time the interfaith meetings inaugurated after the Second Vatican Council had been discontinued. In September 1990 the traditional interfaculty ecumenical symposia held every two years since 1974 were showing signs of nearing collapse. The Zagreb Theological Faculty tried to decide how to protest against what Zagreb theologians viewed as the Serbian Church's political use of the genocide issue and the ecumenical effort, presumably in the service of Milošević's Greater Serbian politics. The Zagreb delegation first asked for a delay until a 'happier moment for dialogue', and then, when the delay was not granted by the Belgrade Orthodox Theological Faculty that was hosting the 1990 symposium, Zagreb refused to participate. The dean of the Belgrade Theological Faculty, Archimandrite Atanasije Jetvić, then issued a number of invitations to individual Catholic priests, mostly liberal clerics, but none attended. The ninth interfaculty symposium was still held at the spa of Fruška Gora in Vojvodina, with Serbian and Slovene religious schools represented. The tenth interfaculty meeting, scheduled for 1992 in Slovenia, did not take place. Between June 1990 and the outbreak of all-out war in Croatia in the second half of 1991, the last traces of ecumenical spirit ebbed away.

In August 1991 the Zagreb weekly Danas published an open letter to the leading Serbian theologian-zealot Archimandrite Atanasije Jetvić written by Fr Luka 
Vincetić, a liberal priest from Slavonia who had taken part in numerous interfaith meetings and vigils. Vincetić thanked Jetvić for the invitation to the 1990 interfaculty symposium, which Vincetic had declined to attend, and seized the opportunity to accuse the Serbian Church of fomenting the conflict which had already taken numerous casualties and generated ethnic cleansing across the Croatian Krajina region.

Are you finally happy, father Atanasije? Are you pleased now? Many Serbs are returning to the Orthodox faith while at the same time killing Croats and others. In the meantime, I read in Pravoslavlje that you have been nominated bishop of Banat. Congratulations ... Your church cries out loudly about Ustasha crimes but remains silent about massacres committed by the Serbian Chetniks. Today the Serbian Church is silent about the genocide against the Croatian people that is being carried out, allegedly in the name of the old injury. But there cannot be any excuse for genocide $!^{45}$

In the first half of 1991, as the war seemed imminent, both church and secular leaders in Serbia and Croatia debated the borders within the Yugoslav six-republic federation. The new Serbian patriarch, Pavle, and members of the Holy Synod had several meetings with Cardinal Kuharic and delegates of the Catholic episcopate to discuss the imminent war threat, but also to put the border issue on the table. The Serbian Church proposed the partition of Bosnia-Herzegovina and the adjustment of borders between Serbia and Croatia, including a 'peaceful exchange of population', about which the former patriarch German had spoken in the earlier-cited interview. ${ }^{46}$ Two church summit meetings took place in 1991. The first was held at Srijemski Karlovci on 8 May 1991 on the initiative of the Catholic Church, and resulted in an appeal against the use of force by the parties in conflict. The day before, however, Patriarch Pavle had been at the historic Jasenovac site officiating at a liturgy in St John's Church and another commemoration under the concrete flower-shaped monument at the memorial site. The second meeting took place at Slavonski Brod on the River Sava on 24 August 1991. This meeting also generated a similar abstract appeal for peace, but without specific references to the causes of conflict, the warring parties or feasible solutions. Cardinal Vinko Puljić told me that the summit meetings of the two churches held in 1991 and 1992 had the border issue on the agenda ${ }^{47}$

Incidentally, the meetings of church leaders coincided with negotiations conducted by the two secular nationalist leaders Franjo Tudjman of Croatia and Slobodan Milošević of Serbia. The 8 May summit meeting of the churches came as a follow-up to the Milošević-Tudjman meeting at Karadjordjevo on 25 March 1991, where the two leaders tried to negotiate a peaceful breakup of Yugoslavia that would include the partition of Bosnia-Herzegovina between Serbia and Croatia (at the expense of the Bosnian Muslims). A few days later Cardinal Kuharić contacted the Patriarchate and initiated the May meeting with Patriarch Pavle. Milošević and Tudjman reached a secret agreement at Karadjordjevo on the partition of Bosnia-Herzegovina. The churches, however, could not agree that the partition would be a right solution, because only the Serbs were able to take a clear stance in favour. The Croatian episcopate now needed adjudication from the pope; but at that particular time the Vatican was still undecided about Yugoslavia. Not long before, in 1988, according to several church leaders and reports by western nongovernmental and ecumenical associations that visited Yugoslavia that year, the Holy See still supported the country's unity and expected a successful democratic transition. In 1986 the American interfaith 
organisation Appeal for the Foundation of Conscience reported after a factfinding mission (3-11 February) that 'the state has achieved openness toward religion with mutual recognition of both parties'. Meanwhile an Italian church review wrote that the Catholics in Yugoslavia were privileged in comparison to those in other Eastern European countries. ${ }^{48}$ In 1990 the Vatican agreed with the Yugoslav Bishops' Conference over restructuring the country into a confederation, but did not encourage partition. ${ }^{49}$ However, when Serbo-Croat hostilities and violence in Croatia escalated with massive casualties through 1991, the Vatican came under pressure from Croatian clergy to recognise Croatia's independence according to the plebiscite of 26 June 1991.

As Vatican diplomacy was lobbying Germany and other European countries to recognise Croatia and Slovenia as independent states, Serbia and the Yugoslav army were warming up for the invasion of Bosnia-Herzegovina. On 15 January 1992 the Vatican, Germany and then other West European countries recognised the two predominantly Catholic Yugoslav republics as sovereign nations. The Belgrade foreign ministry delivered a démarche to the papal pronuncio Einaudi accusing the Vatican of being responsible for the imminent war in Bosnia. The Bishops' Council of the Serbian Orthodox Church held an emergency session in the Patriarchate on 16 and 17 January 1992. The bishops sent a protest letter to Pope John Paul II in which Patriarch Pavle and the hierarchy protested against 'the premature diplomatic recognition of Croatia and Slovenia as independent countries without taking into account the legitimate national and political rights and equality of the Serbian people', and expressed 'a deep sorrow about the pope's one-sided and unchristian attitude toward the ethnic, civil and historic rights and Christian dignity of the Serbian people'. ${ }^{\circ 0}$

The Serbian historian Milan Bulajić, who at the moment of the outbreak of the 1991 war in Croatia was completing research on the role of the Vatican in the Balkans during the Second World War, drew analogies between papal policies in 1941 and 1991, arguing that in both cases the Vatican had played a decisive role in the destruction of the Yugoslav state. ${ }^{51}$ The Serbian school of historiography, influenced by nationalism and by Orthodox church historiography, traditionally exaggerated the role of the Vatican in the Balkans. In recent history, during the critical period between 1981 and 1991, the Vatican had actually kept a low profile in the politics of religion in Yugoslavia. It was only from 1965 to 1975, when Tito and Pope Paul VI isolated the Croatian episcopate and ran domestic church affairs through direct communication between Belgrade and the Holy See, that the Vatican had been able to shape Yugoslav religious politics. From the opening of the Croatian Great Novena jubilee to the outbreak of the Yugoslav war in 1991 the Croatian Catholic episcopate managed the situation autonomously. The fact must be stressed that the Holy See had virtually nothing to do with the pivotal events in Balkan religious affairs of the $1980 \mathrm{~s}$, such as the apparitions of the Virgin Mary at Medjugorje (Herzegovina) (1981-present, managed by the local Franciscans), the Croatian Great Novena (managed autonomously by the Croatian episcopate), the campaign for sainthood for Cardinal Stepinac (the work of Croatian exiles and a private crusade by the Archbishop of Zagreb, Cardinal Kuharic), or, finally, with the conflict between Croatian Catholicism and Serbian Orthodoxy described in this article. It was an independent decision of the Croatian episcopate to rebuff the Serb church leaders' initiative for a unilateral apology by the Catholic Church (at that time the chairman of the Bishops' Conference was Archbishop Kuharić; the ecumenical pioneer Dr Franić, who served as the cochairman of the Conference, retired in 1988). The last occasion on which the Holy See took a direct initiative was in 1983-84 
when Pope John Paul II was considering a visit to Yugoslavia. The pope seemed to be willing to take part in an interfaith commemoration dedicated to the victims of Yugoslav ethnic massacres during the Second World War. However, by 1989 the pope was concentrating his attention on Poland and the Soviet Union (where issues of increasing concern were growing Catholic-Orthodox tension and the question of the relegalisation of the Greek Catholic Church in Ukraine). The Holy See left the management of Balkan affairs to the Croatian episcopate alone. Granted, the papal pronuncio Francesco Colasuonno attended all Croatian episcopal conferences, and the pope advised Croatian bishops through meetings ad limina apostolorum, but the Vatican did not have any specific 'policy' of its own concerning the Yugoslav church and social crisis in the late $1980 \mathrm{~s}$. The Balkan crisis after the death of Tito definitely deserved more attention, even direct intervention, from the headquarters of the Catholic Church. The Vatican would be back as the chief actor on the historic stage in the Balkans in January 1992 (with the diplomatic recognition of the secessionist Catholic republics), then again in 1993 when the pope urged the Croatian and Bosnian episcopate to oppose the Tudjman regime's policy of partition of BosniaHerzegovina, and finally between 1994 and 1998, when there were three papal visits to Croatia and Bosnia-Herzegovina.

\section{Balance Sheet}

Papal-Protestant pseudo-Christianity and quasi-churches have no way of escaping their agony and imminent death except by bowing their heads and repenting before our Lord Jesus Christ and his Orthodox Church. Repentance is a panacea for all sins; it is a remedy bestowed on us by God who loves us all.

\section{Justin Popovićs2}

The communist system and the Second Vatican Council created a historic opportunity for rapprochement between Serbian Orthodoxy and Croatian Catholicism. Communism was a common enemy and the churches might have overcome their differences and forged an alliance against it. However, Yugoslav Titoist communism was in some respects more dangerous for the churches than communism in other countries, precisely because during the period under consideration it was relatively soft. The Titoist system developed a pseudoreligious, as it were 'ecumenical' character, epitomised in the slogan 'brotherhood and unity'; it was communism that was said to bring the various nationalities together, in contrast to religion which, as official Yugoslav historiography taught (and the experience of the Second World War confirmed), spread hatred, abetted extreme nationalists and perpetuated conflict in this multiethnic country. The Second Vatican Council urged an interfaith 'fraternal' dialogue which would lead towards ecclesiastical rapprochement; one aim was to undermine the legitimacy of the Titoist communist system and its cohesive ideological function in multiethnic Yugoslavia.

In spite of the frequent references to religion in the Yugoslav debate, a massive literature on the recent Yugoslav conflict includes relatively few studies on the role of religious institutions..$^{53}$ Even though some volumes deal with religion in the former Yugoslavia, interfaith relations, as an issue of high importance, have been largely ignored. It is taken for granted that the churches have always been captives of an immutable, perpetual and 'ancient' hatred. This perspective mirrors the former Yugoslav regime's attitude toward religion, as well as the views of the Serbian 
school of historiography and some influential western viewpoints on this topic. ${ }^{54}$ This article aims at illuminating the complexity of interconfessional relations in the former Yugoslavia. Mutual distrust in the churches has for centuries coexisted with the desire for cooperation and the ideal of Christian unity. Sectarianism and spite have emanated from zealot circles in the mainstream religious institutions and have grown in times of crisis. To a large extent the collapse of ecumenical cooperation was also a byproduct of inappropriate policies pursued by religious leaders in the domains of interfaith relations, church-state relations and interaction between national churches and ethnic nationalism. The church history of the Yugoslav peoples knows ecumenical enthusiasts as well as antiecumenical zealots, but in the most critical moments of recent history - that is, during the Second World War and in the last decades of communism - there were neither suitable leaders nor ecumenical enthusiasts among the hierarchs of the two major Yugoslav churches. The characters and aptitudes of these men corresponded neither to the gravity of the crisis nor to the complexity of interfaith relations in this multiethnic country. Hypothetically, the Yugoslav 'sister churches' could have exchanged apologies and achieved reconciliation before the crisis entered its critical stage (that is, before the access to political power of the ethnic leaders, Milošević and Tudjman, or even - the most optimistic variant - before the death of Tito). With more leaders like Archbishop Franić, the churches could have utilised religion as a counterweight to ethnic tensions instead of making it a catalyst of the conflict. Franic understood the Second Vatican Council better than Cardinal Kuharić did. If rapprochement had been reached, the churches could also have slowed down the progress of secularisation. Interfaith cooperation might have improved the communist system, encouraged the regime's liberals and accelerated the country's transition to democracy. The Yugoslav disaster might have been averted.

But neither of the two major Churches had great leaders in the time of trial. Cardinal Kuharić was indeed a good pupil of his wartime predecessor Cardinal Stepinac. When the crisis reached its pinnacle in 1998, Archbishop Franić was sent prematurely into retirement. Meanwhile, during the critical period of the Milošević takeover (1987-89) the Serbian Church was led by the ailing octogenarian German, while the influence of nationalists and zealots grew in the clerical rank and file.

Although the leaders of neither church rose adequately to the challenge, there is nevertheless a striking difference between the two churches as far as their liability for the collapse of ecumenism in Yugoslavia is concerned. It could fairly be said that ecumenical dialogue all along had been obstructed by the Serbian Church and that there was more enthusiasm for it in the Catholic Church. It was Rome that initiated ecumenical dialogue and other reforms coming out of the historic Second Vatican Council. Catholicism is more diverse than Serbian Orthodoxy and operates with a system of 'checks and balances'. Catholicism also has richer and more diverse human resources than Serbian Orthodoxy, whose churchmen differ only in the degree of their nationalist sentiment; only a few of them can possibly be described as moderate nationalists. The young Croat Catholic leaders of the postcommunist era, Archbishops Josip Bozanić (Zagreb) and Vinko Puljić (Sarajevo), demonstrate how their church has moved on from the position of figures such as Stepinac and Kuharic (although these two anticommunist crusaders were sent into history with papal honours). By contrast, the Serbian Church in the 1990s continued the course it had followed in the 1960 s, built on a precarious balance between moderates and zealots; and now the influence of the latter was growing. Thus, although Patriarch Pavle (Stojčević) was elected from the ranks of moderates, zealots such as Amfilohije, 
Atanasije and others have had a significant influence on church policy.

The consequence of the Serbian Church's demand that the Croatian Church apologise was that the two churches began to behave like states in a balance of power system rather than two religious institutions sharing common traditions, beliefs, values and practices, and the same God. ${ }^{55}$ Ethics was put to the service of politics. Serbian pressure only provoked Croat Catholic resentment and emboldened nationalist extremists. Although the Serbian demand for apology had its religious and ethical rationale, and was based on historical facts, albeit exaggerated, the Serbian Church did not really allow the Croatian Church enough time or opportunity to find a way of solving the complex issue. According to the liberal Croatian theologian SagiBunić, the chief problem was 'political thinking' on the part of the Serbian Orthodox Church. In 1990 Sagi-Bunić argued that the Serbs never really wanted an apology but only 'the humiliation of Catholicism while keeping Croatian nationalism in check'. ${ }^{56}$ At the same time, the Catholic party was itself far from apolitical. Croatian Catholic leaders never brought themselves to give serious consideration to the possibility of meeting the apology request in some form. The question remains: why could not the Croatian ecclesiastical authorities have released some kind of apology as early as 1968 during the first ecumenical summit meeting or in the mid-1970s on the occasion of the Great Novena?

By the 1980s the time was no longer ripe for an apology. The Croatian Great Novena was a nationalist mobilisation under religious symbols. The Stepinac campaign was a political campaign in service of the anticommunist struggle, but also a nationalistic movement with anti-Serbian overtones. Stepinac was a nationalist icon at least symbolically associated with Croatian fascism. The Stepinac campaign was also part of the genocide controversy of the 1980s which seriously damaged ethnic relations. ${ }^{57}$ The advocates of Stepinac could have taken into account the Serbian Church's negative response, as well as the infelicitous timing. The reassessment of Stepinac's wartime role could have been postponed until a more auspicious occasion.

Extreme nationalism, as the Vatican Council and the Rome Synod of 1971 had taught, was not the right weapon for fighting communism. If the Yugoslav Christian churches had become reconciled they might have delegitimised the communist system which claimed that only under such a system could the Yugoslav peoples live peacefully together. The allied churches could then have created stable conditions in the country and made a peaceful transition feasible. The worst alternative outcome for the churches would have been another genocidal ethnic war in which ethnic and religious nationalists marched side by side; but that is what happened in the $1990 \mathrm{~s}$. Small wonder it is now difficult to reassure millions of people in the former Yugoslavia that Tito and the communists created a better world.

The two major Christian churches of Yugoslavia missed the chance to save the face of religion as the enduring preserver of civilising values which would provide an alternative to both the discredited ideologies of communism and nationalism. The Serbian Church remained suspicious towards what the Serb religious leaders viewed as another piece of trickery like the creation of the Uniate churches. Croatian Catholicism, for its part, did not implement the Council's reforms. The construction of the cult of cardinal Stepinac signified the revival of extreme nationalism and neoUstashism. Some Croatian church policies had played into the hands of Serbian zealots and neo-Chetniks. In the meantime the Vatican, pursuing the Council's idea of autonomous national bishops' conferences (as well as the use of ethnic nationalism as another weapon against communism), became less interested in directly influencing Balkan affairs. In the 1980 s the Vatican left the two rival churches mired 
in their petty Balkan feuds. These feuds were part of the oncoming disaster. Pope John Paul II could possibly have intervened in the Balkan church dispute in the early 1980 s, but the chance had by now been missed. When the Vatican came back to the rough Balkan terrain in 1992, it was too late to prevent the catastrophe which had already occurred; and one of the factors which had caused it was the failure of the Yugoslav interfaith dialogue.

\section{Epilogue}

After the 1991-95 wars in Croatia and Bosnia-Herzegovina the rival churches of Serbia and Croatia continued the course in interfaith relations begun in the 1960s. This course could be briefly described as intransigence with sporadic displays of ecclesiastical diplomacy. While the postcommunist Croatian nationalist regime established Catholicism as the de facto state religion and the Stepinac cult as the key patriotic symbol, the Serbian church and Serb nationalists established cults of martyrdom of Serbs in the Second World War and published books portraying Cardinal Stepinac as the 'spiritual instigator' of genocide. ${ }^{58}$ In 1995 the Zagreb Archdiocese issued a collection of allegedly authentic wartime sermons by Stepinac (earlier kept in secret church archives) as evidence of the prelate's humanitarian work and criticism of the Ustasha regime for its excessive cruelty. ${ }^{59}$ In 1997 the renovated Cardinal Stepinac shrine was opened in Zagreb Cathedral. The Croatian government and the church also had a nine-foot bronze statue of Stepinac, who was becoming the nation's new founding father, erected in his native village of Krašić. Local authorities began building monuments to Stepinac in every village. In the meantime, the Vatican concluded the beatification process and announced that the head of the Roman Catholic Church would come to Croatia in October 1998 for the beatification of the servant of God Alojzije Stepinac.

As the date for the beatification in Croatia approached, foreign Jewish organisations (and some individual Croats of Jewish descent) vehemently protested against it. Early in 1998 the Simon Wiesenthal Center asked the Croatian authorities to halt the beatification. A Croatian human rights organisation close to the regime replied angrily, stating that 'the Jews cannot appropriate the exclusive right to pass historical judgments and to bear the aura of the only martyr-nation, because many other nations, such as notably the Croatian nation, have suffered too. ${ }^{\prime 60}$ The Catholic Church announced that 'according to solidly-based data' Cardinal Stepinac 'saved several hundred Jews during the Second World War, either by direct intervention, or by secret prescripts to clergymen, including mixed marriages and conversion to Catholicism, as did some Righteous in other European countries ...' ${ }^{61}$ On the basis of documents in possession of the Catholic Church, the Croatian government and the church twice requested Yad Vashem (the Jerusalem-based organisation devoted to the remembrance of Holocaust victims) that Stepinac be honoured as 'Righteous among the Nations', but Yad Vashem declined.

In October 1998 Pope John Paul II visited Croatia for the second time since the fall of communism. On 3 October at the national shrine of Marija Bistrica he proclaimed Stepinac a blessed martyr of the Roman Catholic Church and commemorated him again the next day at a grand ceremony in the Adriatic port city and ancient diocesan centre of Split. According to the pope, Stepinac had been a martyr 'to the atrocities of the communist system' and a 'humanist who opposed the three twentieth-century evils of Nazism, fascism, and communism'. ${ }^{62}$ In the words of the archbishop of Zagreb Josip Bozanić, 'Cardinal Stepinac has become a compass that makes possible 
proper orientation for the Croatian people'. ${ }^{63}$ The two church events were the most grandiose religious gatherings in Croatia since the 1984 National Eucharistic Congress and the conclusion of the Great Novena 'Thirteen Centuries of Christianity among the Croatian People'. ${ }^{64}$

From the vantage point of the Holy See, the Stepinac case was expected to help the cause of the ongoing procedure to beatify the wartime pope Pius XII, who has been continuously attacked, especially from Jewish circles, for his alleged silence about the Holocaust. ${ }^{65}$ The beatification of Cardinal Stepinac was also part of the Catholic Church's construction of a new mythical history of the twentieth century. By constructing the myth of a Christian leader who allegedly bravely opposed both fascism and communism, the church was seeking to sustain another great myth - that of the church's 'neutrality' in the landmark twentieth-century clash between right-wing and left-wing ideologies and movements. Finally, on the Balkan front, the Stepinac myth operated as a powerful weapon utilised by one of the warring factions: Stepinac as would-be saint repels and curbs Serbian nationalism; the church's past is whitewashed, Croat pride is boosted and the crucial connection between the Catholic Church and Croatian nationhood is underlined.

In anticipation of the beatification and papal visit, the Serbian Orthodox Church responded. In May 1998 the Bishops' Council of the Serbian Orthodox Church canonised eight new Serbian saints. Although many clerics and faithful in the Serbian Church expected that the answer to Stepinac's beatification would be the canonisation of the anti-Catholic and anticommunist Bishop Nikolaj Velimirović, whose relics were solemnly transferred to Serbia from the USA in 1991, church leaders chose a more telling response. At its regular spring session in the Belgrade Patriarchate the Bishops' Council announced the forthcoming canonisation of eight martyrs. Seven of the new saints were executed between 1941 and 1945 by the Ustashas, and one by the communists. The following church leaders, priests and believers were to become new martyrs (novomučenici) and members of the Assembly of Saints (Sabor svetih) of the Orthodox Church: Metropolitan Dositej Vasic of Zagreb, who was imprisoned and beaten to death by Croat Ustashas (an allegation published in Pravoslavlje that Catholic nuns participated in his torture was included in the official saintly biography); Metropolitan Archbishop Petar Zimonjić of Sarajevo, killed by Ustashas at Jasenovac; Bishop Platon Jovanović of Banja Luka, executed by Ustashas near Banja Luka and thrown into a river; Bishop Sava of Karlovac, killed by the Ustashas; Archpriest Branko Dobrosavljević, tortured and killed by the Ustashas; Archpriest Djordje Bogić, tortured and killed by the Ustashas; the Serb peasant Vukašin, a parishioner from Klepci in Herzegovina who, according to survivors' testimonies, died under torture while calmly telling his executioners 'Just keep on doing your business, son'; and Metropolitan Joanikije Lipovac of Montenegro, executed by the communists in 1945 during an attempt to escape to the West. ${ }^{66}$ The proclamation of new Serbian saints in May 1998 was a response to the Stepinac beatification; their solemn canonisation ensued two years later. In the meantime the list of the new martyrs had increased by one: Rafail, who was abbot of the Sišatovac monastery near the Serbo-Croatian border during the Second World War. He was also a victim of the Ustashas and died under torture in the prison camp of Slavonska Požega. The solemn canonisation of the new Serbian saints took place during the central commemoration of two thousand years of Christianity on 21 May 2000 at Saint Sava's Cathedral in Belgrade.

The 1998-2000 saint-making operations in the two churches contributed to the construction of the new Balkan nations of Serbia and Croatia. The Jasenovac myth 
and the Stepinac myth have become pillars of newly-forged national identities in the two largest successor nations of the former Yugoslavia. The historic strife between Catholicism and Orthodoxy in Yugoslav states has thus been conveyed into the twenty-first century.

\section{Notes and References}

1 Research for this article was carried out in the archives and offices of state commissions for relations with religious communities affiliated with the City Council of Split, Croatia, then the Socialist Federal Republic of Yugoslavia, and the same commissions affiliated with the Association of Communes of the province of Dalmatia, Croatia. I also obtained invaluable information through Vitomir Unkovic, counsellor and general secretary of the commission for relations with religious communities of the Executive Council of the Assembly of the Socialist Republic of Croatia (1974-90), and Radovan Samardžić, the secretary of the federal commission for religious affairs at Belgrade (1972-92). I conducted numerous interviews with religious dignitaries and state officials in charge of religious affairs in the former Yugoslavia, and ran a column 'Religija i politika' in the Croatian weekly newspaper Nedjeljna Dalmacija (1988-91). The bulk of the research was done between 1985 and 1991 and updated during my work on my doctoral dissertation at the University of Minnesota and during my postdoctoral research at the US Institute of Peace and the Woodrow Wilson Center in Washington DC from 1997 to 1999. See Vjekoslav Perica, Religious Revival and Ethnic Mobilization in Communist Yugoslavia, 1965-1991: a History of the Yugoslav Religious Question from the Reform Era to Civil War (PhD dissertation, University of Minnesota, Minneapolis, 1988) and my forthcoming book on the history of religion and nationalism in the Yugoslav states between 1935 and 2000 , to be published by Oxford University Press in 2001 . Finally I would like to thank the editor of $R S S$ and the anonymous reviewers of this article.

2 John Paul II, Centesimus annus, encyclical letter (Rome, 1991), pp. 9-10.

3 John Paul II, Slavorum apostoli, encyclical letter (Rome, 1985), p. 8.

${ }_{4}$ Quoted thus by Franic in my interview with him in Split, Croatia, in November 1989. The interview was published in the weekly Nedjeljna Dalmacija, 26 November, pp. 11-12.

5 ibid.

- Glasnik biskupije Splitske i Makarske, no. 1, 1966.

7 Juraj Kolarić, Pravoslavni (Veritas, Zagreb, 1985), p. 187.

8 Reports and minutes from the archives of the municipal commission for relations with religious communities in Split, Croatia and the municipal committee of the League of Communists of Croatia, Split (various documents, notes, reports from 1973, 1978, 1980, 1982, 1985).

9 Petar Čebić, Ekumenizam i vjerska tolerancija u Jugoslaviji (Niro mladost, Belgrade, 1988), pp. 170, 182.

10 ibid., p. 182. Also reported in the Glasnik Srpske Pravoslavne Crkve, no. 12, 1964, p. 490.

1 Hansjakob Stehle, Eastern Politics of the Vatican, 1917-1979, trans. Sandra Smith (Athens, Ohio, 1981).

12 See Vladimir Dedijer, Novi priloži za biografiju Josipa Broza Tita (Liburnija, Rijeka, 1981), especially chs 13 and 14.

13 C̆ebić, op. cit., p. 133.

${ }_{14}$ Kolarić, op. cit., p. 189.

15 Djoko Sljepčević, Istorija Srpske Pravoslavne Crkve (Ostrog, Munich, 1978).

16 Veljko Djurić, 'The Orthodox Church in the so-called Independent State of Croatia', in the church calendar Crkva 1991 (Holy Synod, Belgrade, 1990), p. 84.

17 From my interview with S̆agi-Bunić published in Nedjeljna Dalmacija, 24 June 1990, pp. 14-15.

18 Milan Bulajić, The Role of the Vatican in the Breakup of the Yugoslav State: The Mission of the Vatican in the Independent State of Croatia (Belgrade, 1993), p. 183. 
19 An Information on Some Aspects of the Status and Activity of Religious Communities in Yugoslavia (Federal Commission for Religious Affairs, Belgrade, 1969), p. 12.

20 Archimandrite Dr Justin Popović, Pravoslavna Crkva i ekumenizam (Hilandar Monastery, Salonika, 1974).

${ }^{21}$ Dimitrije Bogdanović, in Vesnik udruženja pravoslavnog sveštenstva Jugoslavije, nos. 525/526, 1971.

22 Jovan Nikolić, in Vesnik, no. 630, 1976. Jetvić replied in Vesnik, no. 634, 1976.

23 Quoted in Ratko Perić, Ekumenske nade i tjeskobe (Bishop's Office, Mostar, 1993), p. 219.

${ }_{24}$ Paul Pavlovich, The History of the Serbian Orthodox Church (Serbian Orthodox Diocese, Toronto, 1989), p. 4.

25 See Milan Bulajić, Ustaški zločini genocida i suđtenje Andriji Artukoviću (Rad, Belgrade, 1986); Radomir Bulatović, Koncentracioni logor s posebnim osurtom na Donju Gradinu (Svetlost, Sarajevo, 1990); Franjo Tudjman, Wastelands of the Historical Reality (Zagreb, 1989); Ljubo Boban, 'Jasenovac and the manipulation of history', East European Politics and Societies, vol. 3, no. 4, 1990.

${ }^{26}$ For more on this jubilee see Vjekoslav Perica, 'The Catholic Church and the making of the Croatian nation, 1970-1984', East European Society and Politics, vol. 14, no. 3, Fall 2000, pp. 532-64.

27 Vecan pomen: Jasenovac mesto natopljeno krulju nevinih 1941/1985/1991 (with summaries in English) (Holy Synod, Belgrade, 1990), pp. 349-52.

28 ibid.

29 Frane Franić, Bit cete mi svjedoci: Zbirka bozicnih, korizmenih i uskrsnih propovijedi, poruka i poslanica (Split, 1996), p. 266.

30 From my interviews with Zdenko Svete, the Yugoslav ambassador to the Holy See (1982-85), and Vitomir Unković, the counsellor at the office of the commissioner for relations with religious communities of Croatia (1974-90).

${ }^{31}$ Religija, politika, društvo, TANJUG news agency, special bulletin (Belgrade, 17 May 1984).

32 From my interview with the chief commission's secretary Radovan Samardžić, Belgrade, July 1989.

33 Bulajić, The Role of the Vatican ..., pp. 183-84. Bulajić was a communist-era diplomat who became a historian. He was a supporter of Milošević from the late 1980s.

${ }_{34}$ Milorad Ekmečić, Stvaranje Jugoslavije 1790-1918 (Belgrade, 1989).

${ }^{35}$ ibid., introduction.

36 Pravoslavlje (newspaper of the Serbian Patriarchate), 15 November 1990.

${ }^{37}$ Svetislav Spasojević, The Communists and I: the Serbian Patriarch German and the Communists, trans. Rt Rev. Archimandrite Todor Mika and Very Rev. D. Stevan Scott (Grayslake, IL, 1991), p. 127.

${ }_{38}$ 'Church - symbol of the Serbs', The Independent, 22 June 1989, p. 4.

${ }^{39}$ Pravoslavlje, 15 November 1990, p. 1.

40 From Bulovićs interview with the Belgrade daily Politika express, cited in the Catholic weekly Glas koncila, 20 May 1990.

${ }^{41}$ Vjesnik, 7 September 1990, p. 6.

42 Perić, Ekumenske nade i tjeskobe, p. 34.

${ }_{43}$ 'Pismo biskupske konferencije Jugoslavije svetom arhijerejskom sinodu Srpske Pravoslavne Crkve', Službene vijesti BKJ, Zagreb, 12 November 1990.

44 Pravoslavlje, 15 December 1990, p. 5.

45 Danas, 13 August 1991, pp. 36-37.

46 In 1990 the Belgrade weekly Novosti published Patriarch German's 1987 interview. See Spasojević, op. cit.

47 According to the cardinal archbishop of Sarajevo, Vinko Puljic, 19 February 1997, at the United States Institute of Peace in Washington DC.

48 TANJUG, special bulletin, 10 March 1988; Jesus (Milan, Italy), May 1988.

49 From my interview with general secretary of the Bishops' Conference Mgr Vjekoslav 
Milovan, Nedjeljna Dalmacija, 18 November 1990.

See reviews of books on the recent Yugoslav conflict, Richard Crampton and Susan L. Woodward, 'Swept under the carpet', Times Literary Supplement, 24 November 1995; Gale Stokes, John Lampe and Denison Rusinow, with Julie Mostov, 'Instant history: understanding the wars of Yugoslav succession', The Slavic Review, vol. 55, no. 1, spring 1996; Sarah A. Kent, 'Writing the Yugoslav wars: English-language books on Bosnia (1992-1996) and the challenges of analyzing contemporary history', American Historical Review, no. 102, October 1997; and Mark Danner, series of essays in The New York Review of Books, November 1997 through April 1998.

${ }^{4}$ Ekmečić, op. cit.; Samuel P. Huntington, The Clash of Civilizations and the Remaking of World Order (New York, 1996).

s5 The concept of the 'balance of power system' was applied as an explanatory instrument by Sabrina Petra Ramet in her analysis of Yugoslav federalism and the national question during the Tito era. Sabrina P. Ramet, Nationalism and Federalism in Yugoslavia, 1962-1991, 2nd edn (Bloomington, 1992).

For a review article on the debate among Yugoslav historians in the 1980s see Ivo Banac, 'The dissolution of Yugoslav historiography', The American Historical Review, vol. 97, no. 4, October 1992, reprinted in Sabrina Petra Ramet and Ljubisa S. Adamovich (eds), Beyond Yugoslavia: Politics, Economics and Culture in a Shattered Community (Westview Press, Boulder, 1995).

${ }^{38}$ For more information on religion in the postwar situation see Vjekoslav Perica's forthcoming book (Oxford University Press, New York, 2001).

59 Juraj Batelja and Celestin Tomić, Propovijedi, govori i poruke zagrebačkog nadbiskupa kardinala Alojzija Stepinca 1941-1946 (Archdiocese of Zagreb, Zagreb, 1995).

60 As stated in a press release by the Croatian Victimological Society (Hrvatsko žrtoslovno drustvo), in response to the Wiesenthal Center's appeal to the Vatican to call off the beatification of Cardinal Stepinac in October 1998. Quoted according to Croatian state television (Dnevnik Hrvatske televizije), 29 September 1998.

61 Josip Krišto, 'Katolicka crkva i židovi u NDH' ('The Catholic Church and the Jews in the NDH'), in Slavko Goldštajn (ed.), Antisemitizam-Holokaust-Antifašizam (Židovska općina, Zagreb, 1996).

${ }_{62}$ 'Pope beatifies Croat prelate, fanning ire among Serbs', The New York Times, 4 October 1998.

6.3 ibid.

64 'The visit of the Holy Father to Croatia' (Hrvatska Biskupska konferencija), available at http://www.hbk.hr, 24 June 1999.

65 On 16 March 1998 the Vatican released one of the most specific statements so far on the Second World War and the Holocaust. The 14-page document, entitled We Remember: $a$ Reflection on the Shoah, was prepared by the Holy See's Commission for Relations with the Jews on the personal request of the pope in order to preserve the memory of one of the worst massacres in history, to improve Catholic-Jewish relations, and to urge Christians that 'whenever there has been guilt on the part of Christians, this burden should be a call for repentance and conversion, as the pope himself put it'. Presenting the document, Cardinal Edward Cassidy stated that it was 'more than an apology ... an act of repentance ... since as members of the Church we are linked to the sins as well as to the merits of her children'. According to some comments by experts and religious leaders quoted in the western press, the church strongly denounced antisemitism and discouraged those who continue to deny the Holocaust, but critics said the document 'was too little, too late, and even a step backward'. Cited from 'Conferenza stampa di presentazione del documento della commissione della Santa Sede per i rapporti religiosi con l'Ebraismo: "Noi 


\section{Vjekoslav Perica}

ricordiamo: una reflessione sulla Shoah"', The Holy See News Service, 16 March 1998; 'Vatican repents Holocaust sins, defends Pius', Reuters, 16 March 1998; and 'Jews bitter over Vatican's Holocaust paper', Reuters, 17 March 1998.

o6 Pravoslavlje, 1 July 1998. 